\title{
KONSEP LABORATORIUM BIMBINGAN DAN KONSELING SEBAGAI UPAYA MENYIAPKAN CALON KONSELOR PROFESIONAL
}

\author{
Desi Alawiyah $^{1}$ Mulkiyan $^{2}$ \\ ${ }^{1}$ Institut Agama Islam Muhammadiyah Sinjai, Sulawesi Selatan, Indonesia \\ e-mail :alawiyahdesi2@gmail.com \\ ${ }^{2}$ Institut Agama Islam Muhammadiyah Sinjai, Sulawesi Selatan, Indonesia \\ e-mail : mulkiyan9296@gmail.com
}

\begin{abstract}
Abstrak
Artikel ini ini bertujuan untuk menawarkan konsep laboratorium bimbingan dan konseling sebagai salah satu gambaran terancangangnya laboratorium dalam mendukung dan mengembangkan potensi mahasiswa. Mahasiswa seharusnya tidak hanya memiliki ilmu konsep dan teoritis semata, melainkan mahasiswa juga harus mendapatkan soft skill. Pengembangan ilmu konsep dan teoritis bisa didapatkan melalui pembelajaran kelas, tetapi pengembangan soft skill mahasiswa didapatkan pada pembelajaran di laboratorium. Mahasiswa butuh mengembangankan soft sikll sebagai bentuk pencapaian pembelajaran dan pengembangan untuk membangun sikap professional. Dikarenakan keberadaan laboratorium sangat urgensi dalam mendidik dan memberikan skill bagi mahasiswa sebagai calon konselor. Sehingga dibutuhkan sebuah konsep laboratorium yang mendukung kebutuhan tersebut. Konsep Laboratorium yang ditawarkan berupa sistem layanan, ruangan laboratorium bimbingan dan konseling, instrumentasi, dan dokumentasi. Sehingga dengan adanya konsep laboratorium bimbingan dan konseling disetiap prodi BKI diharapkan kedepannya mahasiswa bisa mengenal kondisi di sekolah maupun masyarakat secara komprehensif. Tidak menghasilkan lulusan yang cenderung teoritis tetapi minim praktik dan tidak mampu berbuat banyak terhadap lingkungan sekitarnya.
\end{abstract}

Kata Kunci : Laboratorium bimbingan dan konseling, konselor professional

\section{A. PENDAhuluan}

Belajar menjadi hal yang sangat penting bagi setiap orang, baik itu siswa, mahasiswa, maupun setiap individu. Hal ini tidak terlepas dari manfaat dan pentingnya belajar. Dimana untuk memperoleh pengetahuan atau memperdalam ilmu pengetahuan dibutuhkan belajar, baik itu formal maupun dengan nonformal. Dalam undang-undang Sistem Pendidikan Nasional Nomor 20 tahun 2005, 
dikemukakan bahwa pendidikan adalah salah satu usaha sadar dan terencana untuk mewujudkan suasana belajar dan proses pembelajaran agar peserta didik secara aktif mengembangkan potensi dirinya untuk memiliki kekuatan spiritual keagamaan, pengendalian diri, kepribadian, kecerdasaan, akhlak mulia, serta keterampilan yang diperlukan bagi dirinya, masyarakat, bangsa dan Negara (Mustofa Kamil, 2010).

Laboratorium yang sering disebut "lab" adalah tempat dilakukannya riset atau penelitian ilmiah dan eksperimen atau percobaan (Richard, 2013). Tempat ini dapat merupakan ruangan tertutup, kamar atau ruangan terbuka. Berdasarkan Peraturan Pemerintah (PP) nomer 19 tahun 2005 mengenai Standar Nasional Pendidikan dan dijabarkan dalam Permendiknas Nomer 24 tahun 2007, laboratorium merupakan tempat untuk mengaplikasikan teori keilmuan, pengujian teoritis, pembuktian uji coba penelitian, dan sebagainya dengan menggunakan alat bantu yang menjadi kelengkapan dan fasilitas dengan kuantitas dan kualitas yang memadai. Dengan peraturan ini jelas bahwa keberadaan laboratorium bimbingan konseling dibutuhkan karena merupakan sarana pengaplikasian keilmuan BK bagi mahasiswa.

Tantangan pendidikan tinggi era pasca globalisasi adalah menyiapkan mahasiswa yang mampu menguasai teori kritis, yakni teori yang dikembangkan berdasarkan kerangka pikir multibudaya kontekstual, mencerminkan dan meramalkan kehidupan nyata masyarakat, serta berorientasi pada kesejahteraan dan kemasalahan manusia. Pembelajaran yang dikatakan mampu merespon tantangan tersebut adalah yang mengutuhkan pembelajaran kelas, lapangan, dan laboratorium. Pada pembelajaran ini fungsi pendidikan, penelitian, pengabdian, dan fungsi layanan masyarakat sebuah laboratorium harus optimal.

Hal ini erat kaitanya dengan pembelajaran. Kegiatan di laboratorium memegang perananan penting dalam kegitan belajar dan mengajar di samping sebagai tempat praktek. Laboratorium juga dapat dimanfaatkan sebagai tempat belajar dan mengembangkan ilmu pengetahuan. Namun demikian tidak sedikit di 
PTAIN/PTAIS program studi bimbingan dan konseling islam di Indonesia yang belum memenuhi fungsi pelayanan labroratorium, bahkan belum memiliki laboratorium di prodinya.

Untuk itu, pada penelitian ini menjabarkan tentang bagaimana model laboratorium BK yang menjadi bagian dari aktualisasi mahasiswa dalam mengembangkan potensinya. Seperti apa saja struktur, inisiatif, tatanan (setting) fisik, kualitas klien, kualitas konselor dalam proses konseling. Serta bagaimana pelaksanaanya dan kegiatan tersebut apakah dengan adanya laboratorium BK potensi mahasiswa dapat berkembang.

\section{B. HASIL DAN PEMBAHASAN}

\section{Pengertian, Fungsi Laboratorium Bimbingan dan Konseling}

Laboratorium adalah tempat belajar mengajar melalui metode praktikum yang dapat menghasilkan pengalaman belajar dimana mahasiswa berinteraksi dengan berbagai alat dan bahan untuk mengobservasi gejala-gejala yang dapat diamati secara langsung dan membuktikan sendiri dari sesuatu yang dipelajari.

Laboratorium (Lab) adalah tempat riset ilmiah, eksperimen, pengukuran, ataupun pelatihan ilmiah dilakukan. Laboratorium biasanya dibuat untuk memungkinkan dilakukannya kegiatan-kegiatan tersebut secara terkendali. (Anonim, 2007). Sementara menurut (Emha, 2002), laboratorium diartikan juga sebagau sutu tempat untuk mengadakan percobaan, penyelidikan, dan sebagiannya yang berhubungan dengan ilmu fisika, kimia, dan biologi atau bidang ilmu lain. Menurut (Sukarso, 2005) laboratorium ialah suatu tempat dimana dilakukan kegiatan kerja untuk menghasilkan sesuatu. Tempat ini dapat merupakan suatu ruangan tertutup, kamar, atau ruangan terbuka, misalnya kebun dan lain-lain.

Dalam proses pendidikan sendiri, laboratorium adalah tempat proses belajar mengajar melalui metode praktikum yang dapat menghasilkan penglaman belajar, dimana mahasiswa berinteraksi dengan berbagai alat dan bahan untuk 
mengobservasi gejala-gejala yang dilengkapinya secara langsung. Disamping itu, laboratorium juga sebagai tempat untuk mempersiapkan atau melakukan sesuatu kegiatan ilmiah atau tempat bekerja untuk mengadakan percobaan atau penelitian dalam bidang ilmu tertentu.

Laboratorium bimbingan dan konseling adalah unit penunjang akademik pada program studi bimbingan dan konseling, berupa ruangan dengan segala kelengkapan instrument bimbingan dan konseling yang dikelola secara sistematis untuk pelaksanaan pendidikan, penelitian dan pengabdian kepada masyarakat.

Sebagai unit penunjangan akademik pada program studi laboratorium bimbingan dan konseling setidaknya memiliki tiga fungsi, yakni fungsi pendidikan, penelitian, dan pengabdian kepada masyarakat. Fungsi-fungsi laboratorium bimbingan dan konseling diarahkan kepada pengembangan pribadi konselor efektif, kecakapan professional konselor, dan kecakapan hidup abad 21 yang tertuang pada capaian pembelajaran (CP) berbasis KKNI dalam prespektif abad 21. Selain itu optimalisasi fungsi laboratorium bimbingan dan konseling abad 21 perlu diarahkan pada diversifikasi pengembangan bimbingan dan konseling baik pengembangan dasar, fungsional, maupun keilmuan. Fungsi laboratorium ini sesungguhnya jabaran dari pasal 30 peraturan pemerintah No 90 Tahun 1999, yang menegaskan fungsi utama laboratorium adalah sistem pendukung proses pembelajaran dan pendidikan serta penjamin mutu. Laboratorium menunjang segala pelaksanaan pendidikan pada jurusan dalam pendidikan akademik dan atau professional.

Daya dukung yang harus disiapakan adalah sebagai berikut; insfrastruktur laboratorium bimbingan dan konseling yang memadai baik secara kuantitas maupun kualitas;, program yang dikembangkan berdasarkan hasil analisis kebutuhan, terukur, dan vusuble; ketenagaan atau personel yang memenuhi persyaratan baik secara kualifikasi akademik maupun kompetensi; pembiayaan yang terencana dan memadai; sistem manajemen yang demokratis, akuntable, dan transparan. 
Sehingga jelas bahwasaanya fungsi dari laboratorium bimbingan dan konseling adalah tempat yang dijadikan sebagai ruang praktikum bagi mahasiswa dalam pengembangan keilmuan sesuai dengan peran dan fungsi laboratorium.

\section{Kegiatan Laboratorium Bimbingan dan Konseling}

\section{a. Aktivitas Laboratorium}

Kegiatan yang berada di Laboratorium bimbingan dan konseling dirancang untuk mendukung pembelajaran yang lebih mengarah pada terbentuknya kompetensi berbagai aktivitas praktikum, seperti mikro konseling, praktikum konseling baik secara individual maupun kelompok, bimbingan kelompok meliputi Bimbingan pribadi-sosial dan Bimbingan karir. Assemen psikologis baik teknik tes maupun nontes, dan pengajaran teori-teori yang menggunakan media sebagai pembelajaran edukatif.

\section{b. Fasilitas Laboratorium}

Untuk memfasilitasi berbagai aktivitas dibutuhkan sarana dan prasarana fisik untuk mendukung keberfungsian laboratorium bimbingan dan konseling, sehingga yang dibutuhkan oleh laboratorium sebagai berikut:

1. Ruang Kepala Laboratorium

2. Ruang admin/Teknis/Pendukung

3. Ruang layanan individual

4. Ruang layanan kelompok

5. Ruang layanan klasikal

6. Ruang one way screen

7. Ruang audio visual

8. Ruang meditasi

9. Ruang instrument dan media

10. Ruang produk karya dosen atau mahasiswa 
11. WC/Wudhu

12. Tempat ibadah

13. Ruang tamu

\section{c. Sistem Layanan}

1. Layanan praktikum mahasiswa

2. Layanan penelitian dosen dan mahasiswa

3. Layanan bimbingan dan konseling baik kelompok maupun individual bagi mahasiswa, dosen, masyarakat umum, dan stakeholder lainnya.

4. Layanan kerjasama dan kemitraan.

\section{d. Instrumen}

Menurut Anne Anastasi dalam karya tulisnya yyang berjudul "Psycological testing", yang dimaksud dengan tes/instrument adalah alat pengukur yang mempunyai standar yang objektif sehingga dapat digunakan secara meluas, serta dapat betul-betul digunakan untuk mengukur dan membandingkan keadaan psikis atau tingkah laku individu.

Dalam dunia evaluasi pendidikan, yang dimaksud dengan tes adalah cara atau prosedur dimana pengukuran dan penelitian di bidang pendidikan, yang berbentuk pemberian tugas atau serangkaian tugas/baik berupa pertanyaan-pertanyaan yang harus dijawab, perintah-perintas oleh testee, sehingga dapat dihasilkan nilai yang melambangkan tingkah laku atau prestasi. Nilai mana yang dapat dibandingkan dengan nilai-nilai yang dicapai oleh testee lainnya, atau dibandingkan dengan nilai standar tertentu.

Adapun alat instrument yang biasa digunakan adalah sebagai berikut;

1. Tes Intelegensi

2. Tes Bakat Minat 
Volume 7, No. 1, 2021

ISSN (print) : 2442-3217

ISSN (online) : 2716-3806

Homepage : http://journal.iaimsinjai.ac.id/indeks.php/mimbar

3. Tes Kepribadian

4. Tes Motif Berprestasi

5. Sklaa Kepribadian

6. Tes Potensi Akademik

7. Tes Ketahanan dan Ketenangan Berpikir

8. Tes Kreativitas

\section{e. Dokumentasi}

1. Visi, Misi Laboratorium

2. SOP berbagai kegiatan atau layanan

3. Dokumentasi praktikum mahasiswa

4. Dokumentasi hasil penelitian

5. Dokumentasi kemitraan

6. Dokumentasi pengabdian masyarakat

7. Dokumentasi layanan bimbingan dan konseling.

\section{Laboratorium sebagai pengembangan keterampilan professional} konselor

Fungsi utama lamboratorium adalah system pendukung proses pembelajaran dan pendidikan serta penjamin mutu. Laboratorium merupakan pelaksanaan akademik dibidang pendidikan. Laboratorium menunjang pelaksanaan pendidikan pada jurusan dalam pendidikan akademik dan/atau professional (PP No 60 tahun 1999 pasal 30).

Berdasarkan aturan tersebut Laboratorium memiliki peran untuk memfasilitasi mahasiswa dan pendidik mengembangkan kompetensi akademik dan kompetensi profesi melalui tiga bidang yakni pendidikan, penelitian, dan pengabdian. Implikasinya lingkup layanan bagi mahasiswa di laboratorium meliputi dukungan kemampuan atau keterampilan akademik bidang bimbingan dan konseling, dukungan kemampuan atau keahlian 
professional bimbingan dan konseling, pengembangan keilmuan melalui penelitian serta menunjukan kemampuan professional dalam pengabdian.

Pada lingkup pendidikan, mahasiswa menguasai layanan dasar sebagai konselor yang meliputi: kemampuan sebagai ahli perkembangan, ahli layanan konseling individual, konseling kelompok, bimbingan kelompok, ahli pelatihan, fasilitator konseling sebaya, ahli konsultasi, ahli mengkoordinasikan layanan bimbingan serta kemampuan mengola prioritas layanan sehingga layanan menunjukan akuntabilitas.

Pada lingkup penelitian, mahasiswa menguasai kemampuan merancang penelitian, melaksanakan penelitian, mengolah data penelitian dengan mempergunakan statistik, menginterpretasi dan membuat laporan penelitian, menulis jurnal-artikel penelitian.

Pada lingkup pengabdian, mahasiswa mampu memberikan pelayanan bimbingan dan konseling pada konseli sebaya maupun konseli peserta didik sesuai dengan bidang keahlian yang dipilih.

Sehingga secara spesifik kegiatan laboratorium sebagai pusat pengembangan keterampilan profesioan sebagai berikut:

a. Memfasilitasi dan mengkoordinasi matakuliah praktek,

b. Menyelenggarakan pelatihan pengembangan kemampuan/keterampilan layanan ahli,

c. Memberikan penghargaan pengakuan kemampuan/keterampilan,

d. Menyiapkan perpustakaan sumber belajar untuk menunjang pengajaran pembelajaran program studi,

e. Melibatkan mahasiswa pada penelitian pengembangan keilmuan,

f. Memfasilitasi penyelenggaraan penelitian dosen dan mahasiswa,

g. Menyelenggarakan pelatihan dalam lingkup bimbingan dan konseling bagi stake holder, dan

h. Menyelenggarakan layanan ahli bimbingan dan konseling bagi stake holder. 
Laboratorium bimbingan dan konseling adalah unit sumber daya dasar dari program studi bimbingan dan konseling islam yang meliputi tenaga pengajar untuk melaksanakan kegiatan-kegiatan pengembangan ilmu dan kegiatankegiatan pendidikan dan pengajaran dengan menggunakan sarana dan prasarana yang diperlukan untuk itu. Laboratorium juga menjadi tempat bagi mahasiswa untuk mengembangkan dan melaksanakan kegiatan yang menunjang perkuliahan.

Laboratorium bimbingan dan konseling mempunyai hubungan langsung dengan program studi bimbingan dan konseling islam yang mempunyai wewenang untuk mengelola laboratorium. Bahkan fungsi dan tujuan dasar konseling adalah menunjang keberhasilan program dan kegiatan yang secara langsung dikelolah oleh program studi.

Laboratorium bimbingan dan konseling islam dalam menyusun program kegiatananya berkerjasama dengan jurusan serta melibatkan dosen-dosen dalam menggunakan laboratorium untuk kegiatan perkuliahan, penelitian dan pengembangan, serta pengabdian kepada masyarakat.

Laboratorium menjadi unit pendukung utama pembelajaran di perguruan tinggi. Proses penguasaan teori mahasiswa sangat dipengaruhi oleh pembeljaran yang menintegrasikan pembelajaran kelas, laboratorium, dan lapangan. Oleh sebab itu laboratorium bimbingan dan konseling didalamnya harus mencakup: aktivitas/kegiatan laboratorium, sarana dan prasarana/ ruangan bimbingan dan konseling, sistem layanan, instrument, dan dokumentasi.

\section{PENUTUP}

Melalui kegiatan laboratorium diharapkan teori dan konsep yang dipelajari dapat diimplementasikan dalam praktik dan lingkungan yang lebih nyata, baik di sekolah maupun di masyarakat. Kegiatan laboratorium baik yang dilakukan oleh mahasiswa maupun dosen diharpakan memberikan pengalaman kajian yang komprehensif, sehingga menjadi inovasi dalam mengembangkan layanan bimbingan dan konseling. Temuan dan hasil kajian dapat menjadi bahan 


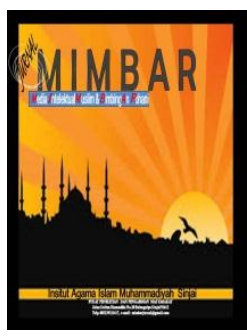

\section{MIMBAR}

Jurmal Media Intelektual Muslim dan Bimbingan Rohani

Volume 7, No. 1, 2021

ISSN (print) : 2442-3217

ISSN (online) : 2716-3806

Homepage : http://journal.iaimsinjai.ac.id/indeks.php/mimbar

dalam memberikan layanan kepada masyarakat yang membutuhkan terutama dalam membantu siswa, guru bimbingan dan konseling (konselor), orang tua, dan lembaga atau masyarakat yang membutuhkan pengembangan sumber daya manusia.

Laboratorium BKI sebaiknya dirancang untuk mendukung pembelajaran yang lebih mengarah pada terbentuknya kompetensi profesional calon konselor sekolah maupun masyarakat. Oleh karenanya diharapkan dengan adanya laboratorium mahasiswa dapat belajar membimbing; belejar mengkonseling bukan sekedar belajar tentang bimbingan; belajar tentang konseling.

\section{DAFTAR PUSTAKA}

Kertiasa, Nyoman, Laboratorium Sekolah dan Pengelolaannya, Bandung: Pudak Scientific, 2006.

Mustofa Kamil, Media Pendidikan dan Pelatihan (konsep dan aplikasi), Bandung: Alfabeta, 2010.

Peraturan Pemerintah Nomor 60 Tahun 1999 tentang Perguruan Tinggi.

Peratuan Pemerintah Nomer 19 Tahun 2005 tentang Standar Pendidikan Nasional.

Richard Decaprio, Tips Mengelola Laboratorium Sekolah, Yogyakarta: DIVA Press, 2013.

Yaya Sunarya, Yusi Riksa Y, dkk. Pengembangan Laboratorium Bimbingan dan Konseling, Bandung: UPI, 2017 